\title{
Collegiate Athletic Opportunities For Women Under Title IX Raises The Proportionality Concern For Men's Sports
}

Nina Compton, (E-mail: ncompton@nmsu.edu), New Mexico State University J. Douglas Compton, Lewis and Roca Jontz Dawe, LLP, Albuquerque, New Mexico

\begin{abstract}
Title IX of the Education Reformation Act was passed in 1972 for the purpose of providing equality between males and females in intercollegiate sports. Since its inception the disparity between men's and women's varsity athletics programs has persisted throughout American colleges and universities. Discrimination and equal protection concerns define the continuing debate of gender equality under the Act. Campuses across the Nation have seen athletic departments add women's varsity sport programs and cut men's programs in order to remain compliant under the Act. This paper explores the equal protection concerns of proportionality amongst enrollment rates and participation rates in intercollegiate athletics. The state of Title IX today remains clouded with questions by college administrators who, after over three decades of enforcement, are employing proportionality concepts as a measure to obtain gender equality in sports. The proportionality practice of cutting men's programs instead of adding women's programs may undermine the purpose of Title IX. This paper is an analysis of the Court decisions and lawsuits that characterize the controversy of Title IX and its legal application to claims of gender bias associated with female athletic programs. The study of this concern is imperative and will shape how college athletic programs are administered in the future.
\end{abstract}

\section{INTRODUCTION}

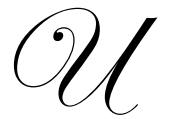

niversities and colleges across the country debate every year what should happen with men's and women's athletic teams at their institutions of higher learning. The decisions are different in college than they are for high school interscholastic programs because the colleges actually produce revenue from certain sporting events. Particularly, football and basketball are large ticket items for men's programs, but, more recently, women's basketball and volleyball have actually produced revenue for the college.

Title IX is an Act created in 1972 under the Education Amendments which prohibits discrimination on the basis of sex in federally funded programs. When intercollegiate athletics is involved, the office of civil rights (OCR) has interpreted Title IX to require schools to provide their male and female students with varsity athletic opportunities in proportion to their numbers in the undergraduate population. This requirement is known as proportionality. Proportionality has become the gold standard for whether a college's varsity athletic offerings comply with Title IX's equal opportunity mandate. The proportionality requirement, however, has received much criticism and scholars have attacked sex-based proportionality for slots on college teams as inconsistent with Title IX's non-discrimination mandate, because the rule gives female students a competitive advantage. ${ }^{1}$

\footnotetext{
${ }^{1}$ Earl C. Dudley, Jr. and George Rutherglen, Ironies, Inconsistencies and Intercollegiate Athletics: Title IX, Title IV, and Statistical Evidence of Discrimination, 1 VA. J. Sports and L. 177, 213-214 (1999) (postulating that Title IX's proportionality requirement is simply a form of affirmative action imposing on universities an obligation to compensate for "societal discrimination"); William E.
} 
Much criticism is made of the proportionality requirement imprinted in Title IX, because it interferes with Title VII's mandate of equal protection between classes. In this instance, it is the class of boys and girls or males and females. This paper examines proportionality concerns for men and women student athletes. Women's sports at the college level are put in the model of careers-open-to-talents, where men and women compete for jobs that are awarded based on relevant talents and abilities. Proportionality is simply a one-man (person), one vote principle that guarantees female students proportional varsity athletic positions even when they have lower levels of athletic interest and ability than do male students. ${ }^{2}$ The issue is whether Title IX funding in intercollegiate athletic programs should be based on proportionality or varsity athletics qualifiers looking at the percentage of students in the qualified applicant pool. ${ }^{3}$

\section{Equal Protection And Gender Equity Under Title IX}

Clearly, Title IX conflicts with the equal protection clause as is shown in Cohen v. Brown University, 123 Educ. L. Rep. 1013, 1025 (1998), which addressed whether the proportionality requirement violates the equal protection clause, because it does not distribute rewards based on individual interest and ability.

Initially, it is important to examine the concept of Gender Equity as it applies to educational athletics programs. ${ }^{4}$ The issue of gender equity is addressed in most aspects of society. It is especially important in sports. Equality is the quality or state of being equal. ${ }^{5}$ This should be consistent for males and females in sports. Gender is a property of certain words whereby they indicate the sex or lack of sex, which they represent. ${ }^{6}$ Gender equity ensures the equality for both sexes. The equal rights amendment required public schools to permit girls to participate with boys in all interscholastic sports, but many cases challenged this idea. ${ }^{7}$

The primary reason more girls and women participate in sport today is that there are more opportunities than ever before. Girls and women still do not receive an equal share of sport resources in most organizational communities. Although female participation is not up to par, government regulations have mandated females be represented in more and more organizations. Congress contributed to the fairness in sports by passing Title IX in the Education Reform Act of 1972. ${ }^{8}$ This title expressed that no person in the United States shall, on the basis of sex, be excluded from participation in, be denied the benefits of, or be subjected to discrimination under any educational program or activity receiving federal financial assistance. This means females are allowed to play in sports in educational institutions. Title IX not only requires equal opportunities for participation, but equal treatment and benefits for athletes with intercollegiate programs. Violations of the law will produce actions for injunctive relief and even for monetary damages.

Thro and Brian A. Snow, The Conflict Between The Equal Protection Clause and Cohen v. Brown University, 123 Educ. L. Rep. 1013, 1025 (1998) (proportionality requirement violates equal protection clause).

${ }^{2}$ Eugene G. Bernardo, II, Note, Unsportsmanlike Conduct: Title IX and Cohen v. Brown University, 2 Roger Williams U.L. Rev. 305, 348 (1997) (discrimination should be found under Title IX only if female students are underrepresented on varsity athletic teams given the percentage of women in the group of students who are interested and able to play varsity athletics); Walter B. Connally, Jr. and Jeffrey D. Adelman, A Universities' Defense To a Title IX Gender Equity in Athletics Lawsuit: Congress Never Intended Gender Equity Based On Student Body Ratios, 71 U. Det. Mercy L. Rev. 845, 904-905 (1994) (criticizing proportionality requirement for Title IX liability to comparisons of women's athletic participants with a number of women in the student body rather than with the "qualified pool" of female students in keeping with the model for liability established by Title VII cases).

${ }^{3}$ Ross A. Jeurewitz, Comment, Playing at Even Strength: Reforming Title IX Enforcement in Intercollegiate and athletics, 8 M.U.J. Gender Soc. Pol'ynl. 283, 348 (2000) ("although Title IX is significantly patterned after Title IV and other civil rights amendments, the courts have refused to look at Title IV's case law for juris prudential guidance"); see Dudley and Rutherglen, supra note 2 at 207-10 (Title IX should follow Title IV case law for how to establish discrimination based on statistics).

${ }^{4}$ Diane Hackman, "The Glass Sneaker: 30 years of victories and defeats involving Title IX and sex discrimination in athletics," Fordham Intellectual Property, Media and Entertainment Law Journal, 556 (Winter 2003).

5 Black's Law Dictionary, Seventh Edition, West Publishing Co. 1999.

${ }^{6}$ Black's Law Dictionary, Seventh Edition, West Publishing Co. 1999.

7 ALR 3d, Vol. 90, Pg. 213.

${ }^{8}$ United States Code Annoted, 1995 Ed., Title 29 205d. 
Schools which provided stipends under the proposal would have to provide stipends for a proportionate number of women athletes. Also, if female students are underrepresented in athletics, their interests must be accommodated unless the institution can show continuous expansion of sports programs. That is, an institution does not have to create more opportunities for females, but can reduce those for males in order to be equal. Title IX has been a movement towards gender equity in schools.

Females also have to deal with finding employment in sports and receiving adequate pay. The Equal Pay Act $^{9}$ requires that employers give equal pay for equal work. It specifically states an employer cannot pay an employee of one sex less than is paid to an employee of another sex where both perform equal work under similar working conditions on jobs requiring equal skill, effort and responsibility. The employee looking for relief under the act must show that the employer pays a higher wage to the opposite sex for equal skill or effort. The institution then must justify any wage difference. ${ }^{10}$

\section{Recent Title IX Cases}

The case of Pederson v. LSU ${ }^{11}$ is typical of recent cases that strictly apply proportionality to find a violation of the Act. Pederson petitioned for an en banc rehearing that was denied in part, and granted in part to extent that the court vacated its original opinion and issued a new opinion that is virtually identical. In its revised opinion, the court again applied the proportionality test in determining whether LSU had violated Title IX. Using this test the Fifth Circuit held that LSU was in violation of Title IX because the student population at LSU was $49 \%$ female, while athletic participation was only $29 \%$ female. The court again found that LSU's differential treatment of women was sufficient to establish an intentional violation of Title IX. Pederson v. LSU mirrored the decision in Pederson v. LSU. $^{12}$ On January 27, 2000, the Fifth Circuit Court of Appeals reversed the Louisiana federal district court's decision and held that Louisiana State University intentionally violated Title IX.

Beth Pederson, Lisa Ollar, and Samantha Clark alleged that LSU violated Title IX by not establishing a women's soccer team. Pederson also wished to establish a putative class consisting of "those female students enrolled at LSU since 1993" who wanted, but were not allowed to participate in varsity women's fast-pitched softball team.

LSU argued that it did not violate Title IX since a proportionality test could not be used when considering violations of the stature. LSU also disputed Pederson's creation of a putative class. Finally LSU argued that even if it had violated Title IX, any such violation was unintentional.

In addressing these issues, the district court held that a proportionality test could be used to determine whether LSU violated Title IX. The court held that since the student population at LSU was $49 \%$ female, while athletic participation was only $29 \%$ female, LSU was in violation of Title IX, a decision that the Fifth Circuit upheld.

The Fifth Circuit did, however, reverse the district court's holding that LSU's violation was not intentional. The Fifth Circuit held that although LSU may have ignorantly violated Title IX, it need not have intended to violate Title IX, but need only have intended to treat women differently. The court relied on statements made by university employees, particularly LSU's athletic director, to determine that LSU intentionally treated women differently.

Finally, the Fifth Circuit also reversed the lower court's ruling decertifying Pederson's putative class. The court held that a class consisting of potential female student athletes who were not given the opportunity to compete in varsity intercollegiate athletics met the necessary requirements for a putative class as set forth by the class action Rule 23 of the Federal Rules of Civil Procedure.

\footnotetext{
${ }^{9}$ United States Code Annoted, 1995 Ed., Title 29 206d.

${ }^{10}$ Marquette Law Review, Vol. 9 Pg. 175.

${ }_{11}$ Pederson v. LSU, 213 F.3d 858 (5 ${ }^{\text {th }}$ Cir. 2000).

12 Pederson v. LSU, 201 F. 3d 388 (5th Cir. 2000)
} 
In summary, the Fifth Circuit held that since LSU did not provide women with the same athletic opportunities as it did men, the school intentionally treated women differently. In doing so, the school intentionally violated Title IX.

\section{Neal v. Board Of Trustees Of The California State Universities ${ }^{13}$}

On December 15, 1999, the Ninth Circuit Court of Appeals reversed a California federal court's decision granting a preliminary injunction and held that reducing the number of athletic scholarships for an over-represented gender is a suitable way for a university to comply with Title IX.

Because the percentage of athletic scholarships given to women was significantly less than the percentage of female undergraduates enrolled in the school, California State University - Bakersfield reduced the number of scholarships for its men's wrestling team. The men's program sought a preliminary injunction preventing the reduction and claimed "gender-conscious remedies are appropriate only when necessary to ensure that schools provide opportunities to males and females in proportion to their relative levels of interest in sports participation." 14 However, the Board of Trustees argued that such a reduction is appropriate to correct an imbalance in the number of athletic scholarships given to a gender as compared to the percentage of students comprised by that gender.

The Ninth Circuit relied on Cohen v. Brown University, ${ }^{15}$ which upheld a preliminary injunction ordering Brown to reinstate its women's gymnastics and volleyball programs in order to comply with Title IX. The Cohen court held that keeping the number of scholarships offered for each gender proportionate to the number of students of each gender is a safe harbor that a university can use to comply with Title IX. Further, Cohen noted that a gender's level of interest in participating in athletics need only be considered if a university does not keep scholarships proportional to enrollment and does not show a history of expanding programs to meet a gender's interest and abilities. The Ninth Circuit reasoned that "adopting Neal's interest-based test for Title IX compliance would hinder, and quite possibly reverse, the steady increases in women's participation and interest in sports that have followed Title IX's enactment." ${ }^{\text {"16 }}$ The Ninth Circuit held that reducing men's athletic scholarships is a proper way for a university to comply with Title IX.

\section{Alston v. Virginia High School League, Inc. ${ }^{17}$}

On August 19, 1997, eleven female student-athletes brought suit under Title IX of the Education Amendments of 1972 against the Virginia High School League (VHSL). The student-athletes alleged that the VHSL denied certain female athletes opportunities to participate in athletics based on their sex in violation of Title IX and the Equal Protection Clause of Amendment XIV of the United States Constitution.

The plaintiffs asserted that the VHSL's scheduling practices treated boys' sports differently than girls' sports, while at the same time forced some girls to stop playing sports that they previously were able to play while no boys were forced to stop playing sports because of schedule changes. The plaintiffs further alleged that the current classifications system deprived girls of opportunities to play all sports of their preference and hindered opportunities for college athletic scholarships.

Virginia schools compete in classifications designated A, AA, or AAA, based on enrollment sizes. Because enrollment fluctuates, some schools change classifications when the league adjusts the grouping every two years. However, the classification system is treated differently among boys' and girls' sports. The sport seasons for girls differ across classifications. AAA schools play basketball in the winter, while A and AA schools compete in the fall. Therefore, if an AAA school is reclassified as AA, a basketball player accustomed to running cross-country, a fall

\footnotetext{
${ }_{14}^{13}$ Neal v. Board of Trustees of the California State Universities, 198 F. 3d 763 (9th Circ. 1999)

14 Id. at 767

${ }_{16}$ Cohen v. Brown University, 991 F. 2d 888 ( $1^{\text {st }}$ Cir. 1993).

${ }_{16}$ Id. at 767.

${ }_{17}$ Alston v. Virginia High School League Inc., 134 Ed Law Rep 180 (W.D. Va. 2000).
} 
sport would have to choose between cross-country and basketball. Conversely, boys' sports are played in the same seasons regardless of classification.

Before the trial, the plaintiffs sought class action certification pursuant to Rule 23 of the Federal Rules of Civil Procedure. Class certification is a case-by-case analysis; there are no legal claims that automatically bind the court to certify any and every class bringing those claims. The plaintiffs proposed class definition included all present and future female students enrolled in Virginia public schools who participate in interscholastic athletics.

In order to receive class certification, the plaintiffs had to satisfy the requirements set forth in Rule 23 . Under this rule, one or more members of a class may sue as a representative party on behalf of all only if (1) the class is so numerous the joinder of all members is impracticable, (2) there are questions of law or fact common to the class, (3) the claims or defenses of the representative parties will fairly and adequately protect the interests of the class.

Only two of the prerequisites to class certification were contested: typicality and adequacy. Both requirements look to the potential for conflicts in the class. In examining the adequacy requirement, the court attempted to uncover conflicts between the named parties and the class they sought to represent. The court also wanted to see if the named parties possessed the same interest and suffered the same injury as the class members. In examining the typicality requirement, the court wanted to ensure that only those plaintiffs who advance the same factual and legal arguments were grouped together as a class.

The court was presented with evidence of a conflict of interests between the named plaintiffs and other members of the class, which precluded certification under Rule 23. A survey presented by the VHSL indicated that the plaintiffs did not adequately represent the interests of all members of their class and that plaintiffs' claims were not typical of their class. A majority of the female student-athletes who responded to the survey expressed a desire to maintain the current system. This conflict prevented the plaintiffs from satisfying the typicality requirement as well as the adequacy of representation requirement. Therefore, the requested relief would not benefit all other persons subject to the practice under attack, as required in a class action.

After the request for class certification was denied, the plaintiffs proposed a narrower sub-class. The narrower class would consist of all present and future student-athletes enrolled in Virginia public schools who were forced to choose between or among sports because of the VHSL's discriminatory scheduling practices. However, the plaintiffs also failed to meet their burden for the narrow sub-class. As a result the court declined to certify the narrower sub-class.

The court would allow the suit to go forth with the plaintiffs as representatives only of themselves.

\section{Horner v. Kentucky High School Athletic Association ${ }^{18}$}

On March 20, 2000, in a split decision, the United States Court of Appeals for the Sixth Circuit held that the Kentucky High School Athletic Associations (KHSAA) did not violate Title IX when it refused to sanction girls' fastpitch softball. This is the Sixth Circuit's second review of the case. Initially, the court reversed the judgment for the KHSAA on Horner's Title IX claim finding that issues of fact "abound[ed]" and remanded the case to the district court.

Lorie Ann Horner, along with eleven other plaintiffs, sued the KHSAA alleging it violated Title IX by not sanctioning girls' fast-pitch softball while sanctioning boys' baseball, the male equivalent sport. The basis for Horner's complaint was that 'KHSAA's failure to sponsor fast-pitch softball for female students diminished the ability of female student athletes to compete for college fast-pitch softball athletic scholarships when compared with male student athletes who played high school baseball and then competed for college baseball athletic scholarships." ${ }^{\text {"9 }}$

\footnotetext{
${ }^{18}$ Homer v. Kentucky High School Athletic Association, 206 F. 3d 685 (6 $6^{\text {th }}$ Cir. 2000)

19 Id. at 687.
} 
Before the case was heard on remand, the Kentucky Legislature amended "if a member school sponsors or intends to sponsor an athletic activity that is similar to a sport for which NCAA members offer an athletic scholarship, the school shall sponsor the athletic activity or sport for which the scholarships are offered. The athletic activities which are similar to sports for which NCAA members offer scholarships are: Girls' fast-pitch softball as compared to slow pitch.

The Sixth Circuit first noted that girls' opportunities were more limited than boys'. The Sixth Circuit then addressed whether or not the KHSAA intentionally discriminated against women by not sanctioning girls' fast-pitch softball. The court held that because "plaintiffs offered no proof on remand that their interests were not being met, despite allowing them to play on boys' fast-pitch softball teams, ${ }^{20}$ they failed to show that any Title IX mandate had been violated at all, let alone intentionally. In making this determination, the majority granted summary judgment for KHSAA by applying a "discriminatory animus" standard that looks to whether an entity's actions focus upon women by reason of their sex and are directed specifically at women as a class. The court found that Horner did not present any evidence to show an intentional violation of Title IX, and therefore, she had no claim against the KHSAA.

\section{Ortiz-Del Valle v. National Basketball Association ${ }^{21}$}

Sandra Ortiz-Del Valle's goal was to become the first female referee in the NBA, as she was the first female referee to officiate a men's pro game, a USBL game in 1991. She refereed a few preseason New Jersey Nets scrimmages in 1992, but despite her credentials, was passed over repeatedly for an NBA referee position. The league gave her varying reasons for denying her a job, which Ortiz-Del Valle's lawyers called a pretext for discrimination.

She brought suit against the NBA on the grounds of gender discrimination in violation of the Title VII. Last spring a jury validated her claim awarding her $\$ 100,000.00$ in damages for lost wages, $\$ 750,000.00$ for emotional distress and $\$ 7$ million in punitive damages. The judgment against the NBA marked the first time that the league had ever lost a discrimination suit.

The NBA moved for judgment as a matter of law or alternatively, for a new trial. The court denied the motion on the condition that the defendant accept reduced damages of $\$ 250,000$ in punitive damages, $\$ 76,926.20$ in lost wages, and $\$ 20,000$ in emotional distress. The court found sufficient evidence to support the jury's finding that Ortiz-Del Valle was discriminated against; however, it felt that the damages were excessive.

As to the emotional distress award, the court concluded that a remitter was proper because there was virtually no evidence of Ortiz-Del Valle needing or having undergone any counseling or psychiatric treatment or of the duration of the mental anguish, its severity or its consequences, that would support the $\$ 750,000.00$ award.

The court reduced the amount of back pay owed Ortiz Del-Valle from $\$ 100,000.00$ to $\$ 76,926.20$. The new amount is the dollar amount she would have earned more as an NBA referee from 1994-1997 than she actually earned from other sources. Ortiz-Del Valle claims that the original $\$ 100,000$ award was based on a jury award of interest on the $\$ 76,926.20$. However, there was no evidence to support this claim.

The biggest reduction in the verdict came in the punitive damages portion of the award, where damages, were decreased to $\$ 250,000.00$, from $\$ 7$ million. The court simply found the number to be excessive, finding the ratio of 58.3 times the remitted amount of compensatory damages to be too high.

The NBA plans to appeal the latest decision, as it is still baffled by the court's decision. Before the start of the 1997-98 season, the NBA hired two female officials, Violet Palmer and Dee Kanter. Both women testified that they had been hired on merit and that they did not believe the league discriminated. NBA officials do not understand how a court can claim that the league discriminates against women becoming officials when they have the only female

${ }^{20} \underline{\text { Id. at } 696 .}$ Ortiz-Del Valle v. National Basketball Association, 42 F. Supp 2 d 334 (S.D. NY, 1999) 
officials in the four major sports. However, the timing of the hiring is conspicuous, coming after the charge was filed and before trial.

\section{Stanley v. University Of Southern California ${ }^{22}$}

Marianne Stanley sued the University of Southern California (USC) for sex discrimination and retaliatory discharge in connection with a contract dispute over her salary as head women's basketball coach. Stanley alleged that her salary was not comparable to that of head men's basketball coach George Raveling and that she was discriminated against and discharged from her coaching position because of her complaint about this unequal pay. After various decisions in the case beginning in 1993, the dispute made its way to the Ninth Circuit Court of Appeals.

The Ninth Circuit initially reviewed Stanley's Equal Pay Act claim. As the court explained, Stanley has the burden of establishing a prima facia case by showing that employees of the opposite sex are paid lower wages for equal work. To prevail she had to show that the jobs of head women's and men's basketball coach are "substantially equal." An analysis of whether the jobs are "substantially equal" focuses on (1) whether the jobs have a common core and are significantly identical, and (2) whether any additional tasks make one of the jobs substantially different.

While Stanley argued that her job was substantially equal to Raveling's, the university argued that there are significant differences because the men's coach bears greater revenue generating responsibility, is under greater media and spectator pressure, and generates more revenue for the school. A defendant may rebut a prima facie case by showing that the disparity in pay is based on some factor other than sex. The university demonstrated that Raveling has a greater experience level and much better coaching qualifications than Stanley does. Nevertheless, Stanley could prevail by showing that the university's explanation is actually an area of discrimination. However, Stanley's unsupported allegations show there was no differences in her qualifications or experience, and did not meet this minimal burden. Therefore, the Ninth Circuit affirmed the lower court's decisions granting the university's motion for summary judgment on the Equal Pay Act claim.

Because of this finding that Stanley did not show any discriminatory conduct on the part of the university, her claims under the Fair Employment Housing Act, Title IX, and the California Constitution also failed. As to her retaliation claim, Stanley alleged that the university retaliated against her because she insisted that the USC honor its initial contract offer for a salary level equal to Raveling's, and would not accept a future offer at a lower level. However, the court found that USC's offer of a multi-year contract remained open and the university did not discharge her in response to any protected activity. In fact, her contract had expired and she was unable to renegotiate a new contract.

Stanely also asserted that there was an express contract formed with USC based on an alleged initial offer of a contract at a salary level equal to Raveling. However, the Ninth Circuit agreed with the lower courts that there was no evidence that there was a meeting of the minds regarding any such alleged offer and therefore, that no contract was formed.

Stanley then argued that an implied-in-fact employment contract existed under which USC led her to believe that she would be rewarded with a multi-year contract with equal pay for equal work if she produced a successful basketball program. The court found no evidence that her express written contract was modified in this way.

Stanley also asserted that USC violated an implied covenant of good faith and fair dealing when it failed to pay her a salary equal to Raveling's. The court held that such a claim requires proof of a valid contract, but that Stanley has no such contract upon which to base her claim. For the foregoing reasons, the Ninth Circuit affirmed the district court's grant of summary judgment in favor of USC.

\footnotetext{
${ }^{22}$ Stanley v. University of Southern California, 178 F. 3d 1069 (9th Cir. 1999) Court Denied 120 S. Ct. 533 (1999).
} 
All of these cases show the constantly changing laws concerning gender equity in sports. Males and females have en equal right to participate and be compensated for the involvement in sporting activities. As society changes, there is a parallel movement in gender equity in sports.

\section{Proportionality v. Careers-Open-To-Talent}

Proportionality, as a way of leveling the playing field between men and women college athletics, was necessary in the first twenty years of Title IX's development. In 1979, the Office of Civil Rights issued an interpretation named the "Policy Interpretation", to set forth guidelines for satisfying Title IX's equal opportunity mandate. A three pronged test was devised and compliance by a college could be shown in any of three ways:

1. A school provides athletic opportunities for its male and female students in numbers substantially proportionate to their respective enrollments;

2. Where the members of one sex have been and are underrepresented among intercollegiate athletes, a school can show a history and continuing practice of program expansion, which is demonstratively responsive to the developing interest in abilities of the members of the underrepresented sex;

3. Where the members of one sex are underrepresented among intercollegiate athletes, and the institution cannot show a continuing practice of program expansion, the school can show that the interests and abilities of the members of that sex have been fully and effectively accommodated by the present program.

Proportionality has continued to be the primary ground for determining gender suits and disproportionate opportunities for women in college athletics which is based on the proportionate population of female students in the university or college. Courts have routinely used this basic standard to rule that a college or university did not give proportionate funds or program support to women college sports in the particular sport challenged.

The careers-open-to-talents model as an alternative concept is an excellent guide for equal opportunity in the workplace for male and female employees. In has been argued that college athletics, as an industry, does not share many of the operational features of the workforce and is not a good playing field to look at dividing program funds for men's and women's college athletics. Where jobs are awarded among interested parties on the basis of ability, the same test is not as easy in college athletics when men's and women's abilities are not the same and they are in segregated sports.

\section{CONCLUSION AND CASE SYNOPSIS}

Proportionality is not justifiable as a meritocracy-based distribution model, but proportionality proponents really do not favor a meritocratic distribution of college varsity athletic slots along the careers-open-to-talents workforce model. The critics of the proportionality requirement do not recommend an abandonment of sexsegregated athletic teams. Allocation of college athletic programs seems to be a distribution of sex-segregated varsity athletic positions between female and male students based on their relative levels of athletic interest and ability. Proportionality must be required to distribute athletic slots so as to maximize the actual participants in the first instance, because it is unlikely that each female student given the opportunity to play varsity athletics, because, women, given the opportunity to compete in varsity athletics have greater utility gains than does a male student who would otherwise have been given the opportunity to play, all of his life. Because we must equate discrimination with equal protection, however, the proportionality requirement cannot be justified by a standard liberal civil rights model in which resources and rewards are distributed based on neutral principles of merit, utility, or capacity to benefit.

The cases of Pederson, Neal, Alston and Horner demonstrate that proportionality is not just based on male and female respective enrollments. The court in Pederson found Title IX discrimination with $49 \%$ female enrollment and only $29 \%$ athletic participation from females. The decision in Neal permitted California State University to comply with Title IX by reducing the number of men's wrestling scholarships, but did not base compliance with Title IX on the gender's level of interest in athletics participation. A similar court finding in Alston could not show discrimination under Title IX for scheduling practices which treated boy's sports differently than girl's sports, and did not allow class action certification because of the conflicts within the classes of girls. Likewise, the Horner case was 
unsuccessful in lobbying for fast pitch softball as a girl's sport in high school when it was ruled that the plaintiff could not show a discrimination feature. The court found that the school rational for non-sponsorship in high school was not focused on the girls by reason of their sex, and was not directed to them as a class. The case analysis in both OrtezDel Valle and Stanley evidence how equal pay claims can pay different dividends than Title IX discrimination claims. Moreover, the Ninth Circuit in Stanley recognized that coaching positions for college basketball men's programs are significantly different than coaching positions for women's programs because of the media pressure and the revenue generating responsibility associated with coaching in a male college sport.

Proportionality is probably best justified as a perfectionist resocialization measure aimed at providing girls with a set of alternative viable conceptions of themselves either through the role modeling affects of having visible college varsity female athletics or, indirectly, through helping to change the social meanings attached to athleticism, specifically, and physical agency, more generally. Proportionality is thus best justified on the grounds that it encourages girls to develop a set of traits, skills and possible self-conceptions that are considered important for their future success and also important, more generally, for a rewarding human life.

\section{NOTES}




\section{NOTES}

